\title{
Suitability of Different Food Types for On-Feeding and Juvenile Production of European Grayling, Thymallus thymallus, under Intensive Farming Conditions
}

\author{
Franz Lahnsteiner ${ }^{1,2} \&$ Manfred Kletzl ${ }^{1,2}$ \\ ${ }^{1}$ Federal Agency for Water Management, Institute for Water Ecology, Fisheries and Lake Research, Mondsee, \\ Austria \\ ${ }^{2}$ Fishfarm Kreuzstein, Oberburgau, Unterach, Austria \\ Correspondence: Franz Lahnsteiner, Federal Agency for Water Management, Institute for Water Ecology, \\ Fisheries and Lake Research, Scharfling 18, A-5310 Mondsee, Austria. E-mail: franz.lahnsteiner@baw.at
}

\author{
Received: September 23, 2014 Accepted: November 25, $2014 \quad$ Online Published: December 15, 2014 \\ doi: $10.5539 /$ jas.v7n1p161 \\ URL: http://dx.doi.org/10.5539/jas.v7n1p161
}

\begin{abstract}
In the present study on-feeding and juvenile production of European grayling, Thymallus thymallus, was tested with a commercially available fry food for salmonids (FSS) and a specific self-made fry food containing zooplankton components (DFZO) under intensive farming conditions. Live zooplankton food was used as control.

Rearing of grayling was not possible with FSS as in $>70 \%$ of the fish malformations manifested circa 30 days after on-feeding. Malformed fish had sharply bent tails and gas accumulations in the coelomic cavity and intestine. These alterations were reversible and compensated when fish were fed on a live zooplankton diet instead of FSS for 2 weeks.

When grayling were fed with DFZO during the first 14 days and with FSS thereafter, survival rates $49 \mathrm{~d}$ after first feeding were $85 \pm 3 \%$, increase in total length was from $15.7 \pm 0.9 \mathrm{~mm}$ (day of first feeding) to $27.1 \pm 1.2$ $\mathrm{mm}$ (day 49) and in weight from $20 \pm 2 \mathrm{mg}$ to $110 \pm 13 \mathrm{mg}$. The percentage of malformed fish was $<0.5 \%$. These viability parameters did not significantly differ from fish fed with live zooplankton food.
\end{abstract}

Keywords: larvae, juveniles, Thymallus thymallus, feeding, formulated dry food

\section{Introduction}

Today rainbow trout (Oncorhynchus mykiss) and carp (Cyprinus carpio) dominate European inland aquaculture. Diversification in the food fish sector is considered as a way to develop aquaculture and meet specific market demands. Grayling culture is commercially interesting as water quality requirements and farming methods are similar to other salmonids. A main bottleneck in the production of grayling is the availability of suitable aquaculture feeds for larvae, juveniles and broodstock fish.

The present study deals with the development of feeding regimes for on-feeding and juvenile production. Several investigations indicate that on-feeding of grayling with formulated dry food is possible (Luczynski, Zaporowski, \& Golonka, 1986; Carlstein, 1993). Despite of the promising success of these studies, routine production of grayling and also of different other salmonid species still depends on live food as zooplankton or artemia (Ocvirk \& Vovk, 1986, Harris \& Hulsman, 1991, Kletzl \& Lahnsteiner, unpublished data). Problems associated with the use of dry food are lower survival rates, an increase in size variation, deterioration of water quality resulting in an increased effort to clean tanks, malformations, and increased disease susceptibility (Abi-Ayad \& Kestemont, 1994; Lahnsteiner, unpublished).

Therefore, the present study performs additional investigations on the on-feeding and juvenile production of European grayling, Thymallus thymallus, with formulated dry food. It tests the suitability of a commercially available dry food for salmonid fry and a self-made dry food containing zooplankton components in comparison to live zooplankton food. Experiments were performed first under small scale conditions and then under intensive farming conditions relevant in aquaculture. Fish survival rate, total length, weight and malformations were used as viability indicators. 


\section{Method}

\subsection{Broodstock Fish, Egg Collection and Larvae Production}

Thymallus thymallus derived from a wild population near Mittersill, Salzburg $\left(47^{\circ} 10^{\prime} \mathrm{N}, 12^{\circ} 37^{\prime} \mathrm{E}\right)$. Fish were caught at their spawning sites in a small river by electro fishing. This was the most effective and for the fish most harmless method under the specific conditions. Gametes were stripped and artificially fertilized. Circa 400,000 fertilized eggs were transported to the fish farm Kreuzstein, disinfected with $1000 \mathrm{ppm}$ formalin for $20 \mathrm{~min}$ and incubated in flow through incubators until hatching. Larvae were stocked in the appropriate tanks for the experiments.

\subsection{Food Types}

\subsubsection{Zooplankton Feed}

Live zooplankton was used as control, as it is an optimal starter feed for fish larvae (Støttrup, 2000, Evejemo, Reitan, \& Olsen, 2003, Lahnsteiner, Kletzl, \& Weismann, 2012) and routinely used in the fish farm Kreuzstein. Zooplankton was collected from wild populations from lake Mondsee with plankton nets having a mesh size of $200 \mu \mathrm{m}$ (AquaTech, Kitzbühl, Austria). The nets were dredged behind a boat in a depth of $10-15 \mathrm{~m}$ and at a cruising speed of $0.5 \mathrm{miles} / \mathrm{h}$. The collected zooplankton was washed out of the nets in 201 buckets and diluted to a density of circa 100.000 animals per litre. Density was estimated by counting the number of zooplankton organisms in $1 \mathrm{ml}$ subsamples in Petri-dishes. Subsamples of the zooplankton were taken in 5 day intervals and fixed in $4 \%$ formaldehyde for determination of the species composition. The zooplankton consisted of Daphnia sp. (43 $\pm 32 \%)$, Cyclops sp. $(27 \pm 19 \%)$, and Diaptomus sp. $(30 \pm 22 \%)$.

\subsubsection{Self-Made Formulated Dry Feed Containing Zooplankton Components (DFZO)}

DFZO was produced in 3 different portions with different zooplankton samples due to limited capacities in food processing. The composition of DFZO derived from data of a previous study (Lahnsteiner et al., 2012). It contained lactalbumin, low temperature fish meal, salmon fish oil, lecithin, mineral mixture, vitamin mixture and homogenized zooplankton. The mineral mixture consisted of $216 \mathrm{~g} \mathrm{CaCO}_{3}, 500 \mathrm{~g} \mathrm{CaHPO}_{4} \cdot 2 \mathrm{H}_{2} \mathrm{O}, 0.02 \mathrm{~g} \mathrm{CoSO}_{4}$, $3 \mathrm{~g} \mathrm{CuSO}_{4} \cdot 5 \mathrm{H}_{2} \mathrm{O}, 20 \mathrm{~g} \mathrm{FeSO}_{4} \cdot 7 \mathrm{H}_{2} \mathrm{O}, 90 \mathrm{~g} \mathrm{KCl}, 0.04 \mathrm{~g} \mathrm{KI}, 217 \mathrm{~g} \mathrm{MgOH}, 4 \mathrm{~g} \mathrm{MnSO}_{4} \cdot \mathrm{H}_{2} \mathrm{O}, 40 \mathrm{~g} \mathrm{NaCl}, 1 \mathrm{~g} \mathrm{NaF}, 0.03$ $\mathrm{g} \mathrm{Na}_{2} \mathrm{SeO}_{3}$, and $3 \mathrm{~g} \mathrm{ZnSO}_{4} \cdot 7 \mathrm{H}_{2} \mathrm{O}$. The vitamin mixture contained per $\mathrm{kg} 1500 \mathrm{IE} / \mathrm{mL}$ vitamin $\mathrm{A}, 168 \mathrm{IE} / \mathrm{mL}$ vitamin $\mathrm{D}_{3}, 0.5 \mathrm{mg} / \mathrm{mL}$ vitamin $\mathrm{E}, 0.6 \mathrm{mg} / \mathrm{mL}$ vitamin $\mathrm{B}_{1}, 0.86 \mathrm{mg} / \mathrm{mL}$ vitamin $\mathrm{B}_{2}, 0.43 \mathrm{mg}$ vitamin $\mathrm{B}_{6}, 1.0$ $\mathrm{mg} / \mathrm{mL}$ vitamin $B_{12}, 10 \mathrm{mg} / \mathrm{mL}$ vitamin $C, 5.0 \mathrm{mg} / \mathrm{mL}$ nicotinic acid, and $1.5 \mathrm{mg} / \mathrm{mL}$ panthotenic acid.

Homogenized zooplankton was prepared in the following way. From the zooplankton the water was drained away using a net with a mesh size of $200 \mu \mathrm{m}$. The required amount of zooplankton was weighted, placed in a bowl and homogenized using an immersion blender. One $\mathrm{g} / \mathrm{kg}$ ascorbic acid and $0.25 \mathrm{~g} / \mathrm{kg}$ tocopherol were added as antioxidants. The ingredients listed above were mixed with the homogenized zooplankton for $20 \mathrm{~min}$ using a dough mixer. Then the pastry was spread in a circa $0.5 \mathrm{~cm}$ thick layer on baking trays, dried for $12 \mathrm{~h}$ at $70{ }^{\circ} \mathrm{C}$ and stored air tight in a refrigerator at $4-5^{\circ} \mathrm{C}$ until use.

The 3 zooplankton samples used for food preparation were biochemically analysed. From each sample protein, metabolites, and lipids were extracted with standard procedures (Lahnsteiner et al., 2010). Total lipids, triglycerides and phospholipids were measured with methods of Chaudhry (1989), free fatty acids with the method of Lowry and Tinsley (1976), total carbohydrates according to Chaplin and Kennedy (1986) and protein with the method of Lowry et al. (1951). Glucose, fructose, lactate, pyruvate, and ADP were determined with methods described in Bergmeyer (1985). The used zooplankton samples contained (all values are referred in unites per g zooplankton wet weight) $75.7 \pm 22.3 \mathrm{mg}$ total lipids, $16.6 \pm 15.4 \mathrm{mg}$ triglycerides, $28.7 \pm 13.6 \mathrm{mg}$ phospholipids, $3.9 \pm 1.5 \mathrm{mg}$ free fatty acids, $2.9 \pm 1.3 \mathrm{mg}$ total carbohydrates, $1.3 \pm 0.1 \mathrm{mg}$ glucose, $0.4 \pm 0.1 \mathrm{mg}$ fructose, $43.3 \pm 13.0 \mathrm{mg}$ protein, $6.1 \pm 2.9 \mathrm{mg}$ free amino acids, $446.8 \pm 2.7 \mathrm{nmol}$ lactate, $30.3 \pm 26.8 \mathrm{nmol}$ pyruvate, and $26.7 \pm 27.6 \mathrm{nmol}$ ADP. The dry weight of the samples was $10.2 \pm 1.4 \%$ of the wet weight.

\subsubsection{Commercial Feed}

The commercial feed was an extruded feed for salmonid fry with a pellet size of $0.6 \mathrm{~mm}$ containing immunostimulants, $64 \%$ crude protein, $9 \%$ crude fat, $0.5 \%$ crude fibres, $1.5 \%$ phosphorus, 10000 I.E vitamin A, 1000 I.E. vitamin D3, $480 \mathrm{mg}$ vitamin E, 15,0 MJ digestible energy. Ingredients were fish meal, wheat gluten, wheat, and fish oil.

\subsection{Small Scale On-Feeding Experiments}

Small scale on-feeding experiments were conducted from the time point of first feeding until day 21 after first feeding with FSS, DFZO, and live zooplankton (= control). Each experiment was repeated one time. A number of 
250 grayling, respectively, were stocked in flow through incubators (length $\times$ width $\times$ depth: $70 \mathrm{~cm} \times 40 \mathrm{~cm} \times 20$ $\mathrm{cm}$ ) supplied with ground water of $9 \pm 1{ }^{\circ} \mathrm{C}$ at a flow rate of circa $0.6 \mathrm{l} / \mathrm{sec}$. Zooplankton was fed 4 times per day. In each feed portion circa $4000 \pm 100$ organisms were administered resulting in an organism density of $16 \pm 2$ animals per fish. DFZO and FFS were grinded in a corn mill to a particle size of 300-400 $\mu \mathrm{m}$ and fed continuously for a period of $16 \mathrm{~h}$ per day using an automatic fish feeder. Flow through incubators were cleaned two times daily from remaining food and dead fish were removed and counted.

\subsection{Large Scale Feeding Experiments}

A number of 20.000 fish was stocked in circular tanks with a volume of 1000 1, respectively. Tanks were supplied with ground water as described and at a flow rate of $0.25 \mathrm{l} / \mathrm{sec}$. Feeding was done according to the scheme shown in Figure 1. Each experiment was repeated one time. Food was administered with automatic fish feeders for $16 \mathrm{~h}$ per day during the first 30 days and thereafter for $12 \mathrm{~h}$ per day. Tanks were cleaned two times daily and dead fish were removed and counted. From day 0 to day 21 food with a particle size of $0.3-0.4 \mathrm{~mm}$ was used and then the particle size was increased to $0.6 \mathrm{~mm}$.

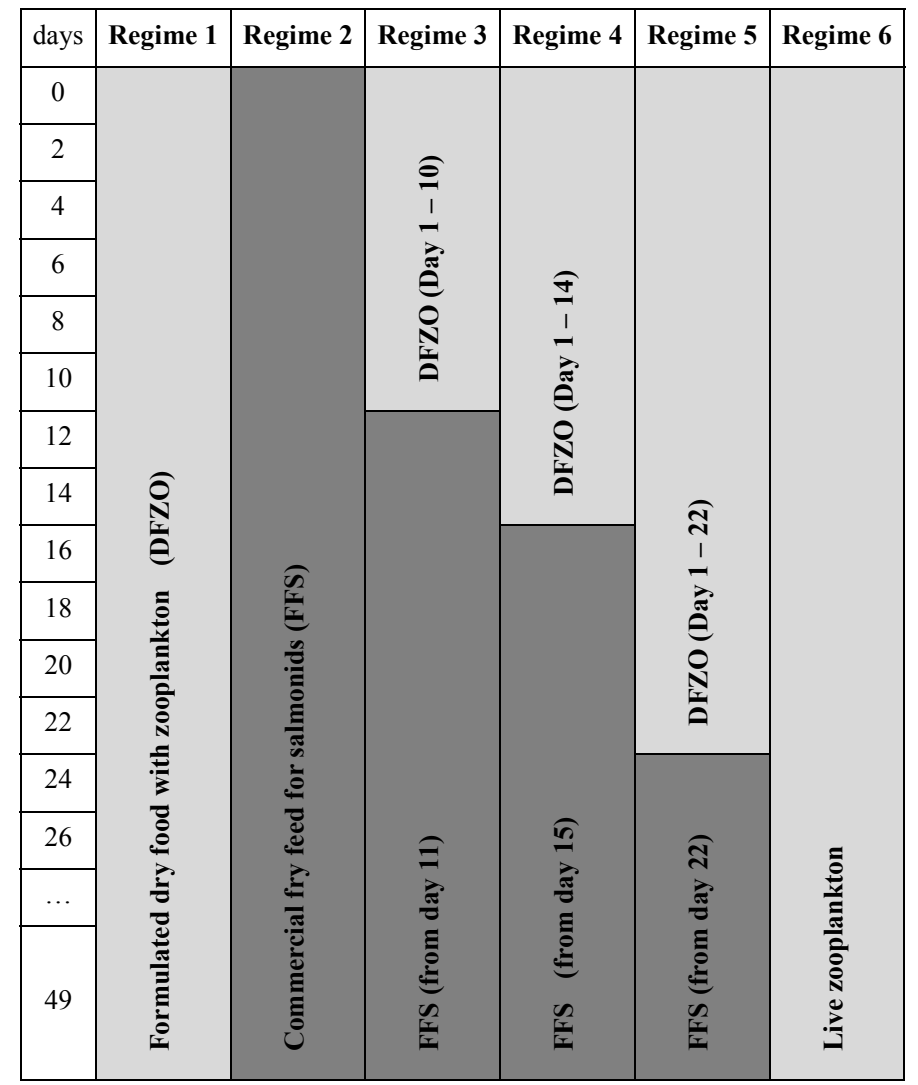

Figure 1. Scheme of the feeding regimes used for the large scale experiment

\subsection{Fish Viability Parameters}

Before sampling fish were homogenously distributed in the tanks by gentle mixing. Twenty fish were randomly taken and killed by prolonged exposure to MS 222. Total length was determined from micrographs taken in the stereo microscope for fish with an age $<30 \mathrm{~d}$. Older fish were measured with a ruler to the nearest $0.5 \mathrm{~mm}$. Weight was determined with an analytical balance to the nearest $\mathrm{mg}$. To record the number of malformed fish, samples with 100 individuals were taken, respectively. Fish were anaesthetized in MS22 in plastic trays, photographed and misshaped larvae were counted from the digitized pictures. Sampling was performed in 7 day intervals. For clarity of data presentation only end points ( $21 \mathrm{~d}$ for small scale experiment, $49 \mathrm{~d}$ for large scale experiment) are reported.

\subsection{Investigations on Fish with Malformations and Abnormal Behaviour}

Fish with malformations and/or an abnormal swimming behaviour were collected and killed by an over-dose of MS222. As malformed fish revealed sharply bent tails and/or enlarged abdominal cavities they were investigated 
on abnormalities in the skeleton and on the occurrence of gas or fluid accumulations in the coelomic cavity. For investigations of the skeleton 20 fish were immersed in glycerol/acetic acid (90:10, w:w) for $48 \mathrm{~h}$ to increase their transparency and thereafter the skin was removed by micro-preparatory techniques. In 20 other fish the tissue was macerated with $10 \% \mathrm{NaOH}$ for $24 \mathrm{~h}$ and the remaining skeleton was softly cleaned by several rinses in distilled water. Both types of samples were investigated in a stereomicroscope on skeletal deformities.

To find out the reason for the enlarged abdominal cavity, 40 fish were sampled. Twenty fish were placed in dry Petri dishes and their abdominal cavity was opened with micro-preparatory techniques to see if fluid had accumulated. Twenty other fish were placed in petri dishes, too, but covered with water and their abdominal cavity was opened as described. Emerging gas bubbles were considered as indicators for gas accumulations in the coelomic cavity. Then the intestine was removed and investigated on the occurrence of intra-intestinal gas accumulations, too. Results were compared with 20 fish from the zooplankton control.

To clarify if malformations and abnormal behaviour were reversible, 250 malformed fish from feeding regime 1 (FSS) were sampled and stocked in flow through incubators as used for the small scale experiments. There, they were fed with live zooplankton 4 times per day as described above. After 2 weeks the fish were re-inspected on abnormal behaviour and malformations.

\subsection{Statistics}

The survival rate and malformation rate were expressed as percentage data of surviving fish and malformed fish, respectively, relative to the total number of fish and reported as mean \pm standard deviation. The sample number was 2 and resulted from two different tanks. Weight and length were presented as mean \pm standard deviation, too. The sample number was 40 deriving from 20 fish, respectively, from two different tanks. For statistical analysis, percentage data were transformed by angular transformation $(\arcsin \sqrt{\mathrm{P}})$ and metrical data by a logarithmic transformation. To determine significant differences in survival rate and malformation rate analysis of variance (ANOVA) with subsequent Waller-Duncan post hoc test was used, to determine significant differences in weight and length, analysis of variance (ANOVA) with Tukey's $b$ - hoc test.

\section{Results}

\subsection{On-Feeding of Grayling Larvae}

Twenty-one days post-feeding the larvae survival rates did not significantly differ between live zooplankton, FFS, and DFZO (Table 1). Larvae weight and total length were significantly higher for larvae fed on live zooplankton than for larvae fed on dry feeds (Table 1). Concerning the dry feeds DFZO resulted in a higher larval weight than FFS, while there were no significant differences in total length (Table 1).

Table 1. Results of on-feeding of Thymallus thymallus with dry food for 21 days. Feeding with live zooplankton served as control

\begin{tabular}{lllll}
\hline Feeding regime & Survival,\% & Malformations, \% & Total length, mm & Weight, mg \\
\hline 1 d before first feeding & - & $0.1 \pm 0.1^{\mathrm{a}}$ & $15.5 \pm 1.8^{\mathrm{a}}$ & $19 \pm 4^{\mathrm{a}}$ \\
Live zooplankton for 21 d & $91.4 \pm 3.2^{\mathrm{a}}$ & $0.1 \pm 0.1^{\mathrm{a}}$ & $23.4 \pm 1.1^{\mathrm{b}}$ & $58 \pm 8^{\mathrm{b}}$ \\
DFZO for 21 d & $92.2 \pm 4.6^{\mathrm{a}}$ & $0.1 \pm 0.1^{\mathrm{a}}$ & $19.7 \pm 1.2^{\mathrm{c}}$ & $30 \pm 5^{\mathrm{c}}$ \\
FSS for 21 d & $87.6 \pm 6.7^{\mathrm{a}}$ & $0.1 \pm 0.1^{\mathrm{a}}$ & $21.1 \pm 0.9^{\mathrm{c}}$ & $35 \pm 6^{\mathrm{d}}$ \\
\hline
\end{tabular}

DFZO: formulated self made dry food with zooplankton, FFS: commercial fry food for salmonids. Data are mean \pm standard deviation. For survival and malformation rate $\mathrm{n}=2$ and resulting from 2 different tanks; for weight and length $\mathrm{n}=40$ deriving from 20 fish, respectively, from two tanks. Values with the same superscript symbol are not significantly different $(P>0.05)$.

\subsection{Feeding of Larvae to Juveniles}

For feeding of larvae to juveniles 7 feeding regimes were tested, i.e. live zooplankton, FFS, DFZO, and a switch from DFZO to FFS at different time points (Figure 1). Mortalities $>50 \%$ were observed when grayling were fed exclusively with DFZO or FFS (Table 2). In feeding regime 1 (FSS) a high percentage of $>70 \%$ of the fish revealed malformations, in regime 3 (switch from DFZO to FSS after $10 \mathrm{~d}$ ) $0.4 \%$, in the other feeding regimes only $0.1 \%$ (Table 2). Total length and weight were highest in feeding regime 6 (live zooplankton), regime 1 (FSS) and 4 (switch from DFZO to FSS after 14 d) and lowest in regime 2 (DFZO). Regime 3 (switch from DFZO to FSS after 
$10 \mathrm{~d}$ ) and 5 (switch from DFZO to FSS after $21 \mathrm{~d}$ ) were intermediate (Table 3). In regime 1 the growth was very variable between the individuals as indicated by the high standard deviation of mean values of total length and weight.

Table 2. Effect of different feeding regimes on Thymallus thymallus juveniles after 49 d. Regime 6 (live zooplankton) served as control

\begin{tabular}{lllll}
\hline Feeding regime & Survival,\% & Malformations, \% & Total length, mm & Weight, mg \\
\hline 1 d before first feeding & - & $0.1 \pm 0.1^{\mathrm{a}}$ & $15.7^{\mathrm{a}} \pm 0.7^{\mathrm{a}}$ & $20 \pm 1^{\mathrm{a}}$ \\
Regime 1 for $49 \mathrm{~d}$ (FSS) & $32 \pm 5^{\mathrm{a}}$ & $74.7 \pm 4.6^{\mathrm{b}}$ & $29.6 \pm 3.1^{\mathrm{b}}$ & $133 \pm 36^{\mathrm{b}}$ \\
Regime 2 for 49 d (DFZO) & $28 \pm 7^{\mathrm{a}}$ & $0.1 \pm 0.1^{\mathrm{a}}$ & $26.8 \pm 1.3^{\mathrm{c}}$ & $96 \pm 11^{\mathrm{c}}$ \\
Regime 3 for $49 \mathrm{~d}(10 \mathrm{~d}$ DFZO, then FSS) & $84 \pm 4^{\mathrm{b}}$ & $0.4 \pm 0.2^{\mathrm{c}}$ & $27.1 \pm 1.2^{\mathrm{c}}$ & $110 \pm 13^{\mathrm{d}}$ \\
Regime 4 for 49 d (14 d DFZO, then FSS) & $85 \pm 3^{\mathrm{b}}$ & $0.1 \pm 0.1^{\mathrm{a}}$ & $30.0 \pm 1.0^{\mathrm{b}, \mathrm{d}}$ & $122 \pm 15^{\mathrm{e}}$ \\
Regime 5 for 49 d (21 d DFZO, then FSS) & $50 \pm 7^{\mathrm{c}}$ & $0.1 \pm 0.1^{\mathrm{a}}$ & $28.0 \pm 1.1^{\mathrm{b}, \mathrm{c}}$ & $97 \pm 14^{\mathrm{c}}$ \\
Regime 6 for 49 d (Live zooplankton) & $86 \pm 4^{\mathrm{b}}$ & $0.1 \pm 0.1^{\mathrm{a}}$ & $31.4 \pm 1.0^{\mathrm{d}}$ & $120 \pm 14^{\mathrm{e}}$ \\
\hline
\end{tabular}

DFZO: formulated dry food with zooplankton, FFS: commercial fry food for salmonids. Data are mean \pm standard deviation. For survival and malformation rate $n=2$ and resulting from 2 different tanks; for weight and length $n$ $=40$ deriving from 20 fish, respectively, from two tanks. Values with the same superscript symbol are not significantly different $(P>0.05)$.

\subsection{Investigations on Fish with Malformations and Abnormal Behaviour}

Malformed fish had sharply bent tails (Figures 2a and 2b) and enlarged abdominal cavities (Figure 2c). These fish swam on the water surface or in the upper 10 to $20 \mathrm{~cm}$ of the water body. They were unable to keep their balance as they swam either on their lateral side, up-side down, or with the head or tail towards the water surface. Examination of the glycerol/acetic acid (for increase in transparency) or $10 \% \mathrm{NaOH}$ (for tissue maceration) treated fish revealed no indications for deformities of the vertebral column or other parts of the skeleton. No fluid accumulations were detectable in the coelomic cavity. Extensive gas accumulations were found in the abdominal cavity (Figures $2 \mathrm{~d}$ and $2 \mathrm{e}$ ) and/or in the intestine of $82 \%$ (Figure $2 \mathrm{f}$ ) of the malformed fish while no gas accumulations were found in the control fish. Gas accumulations probably led to expansion and enlargement of the abdominal cavity and to compression and deformation of the vertebral column (Figures $2 \mathrm{~d}$ and $2 \mathrm{e}$ ).

When fish with malformations were fed with live zooplankton, the percentage of malformations or abnormal behaviour decreased from $100 \%$ to $2 \%$ after 14 days. During this period the mortality rate was $<10 \%$.

\section{Discussion}

During the initial feeding period (from 0-21 days) the survival rates of fish were similar with FSS, DFZO and with live zooplankton while the increase in weight and length was food specific and highest with live zooplankton. These data establish previous ones (Støttrup, 2000; Ocvirk \& Vork, 1986) that live zooplankton is an optimal starter feed for fish larvae. It is also the starter food in nature and therefore the digestive tract of larvae must be considered to be best adapted to this food type (Støttrup, 2000; Ocvirk \& Vork, 1986).

From the present study it becomes evident that screening periods of 21 days were too short to make clear conclusions about the suitability of different food types for on-feeding and on-growing of grayling. Contrary, the 49 day experiments allowed the following clear conclusions about the suitability of the different feeding regimes:

(1) From all tested feeding regimes only regime 4 (DFZO during the first 14 days and FSS thereafter) resulted in similar development of grayling as the live zooplankton control (regime 6), i.e. survival and growth were high and malformations minimal. These data show that specific zooplankton components were necessary as food ingredients for early development stages of grayling. Zooplankton is a specific and multi-component mixture of proteins, lipids, free amino acids, enzymes and metabolites as indicated by the present and previous analytical data (Sekino et al., 1997; Mitra, Mukhopadhyay, \& Ayyappan, 2007). However, until now it is unclear which components of the zooplankton and of other live diets are essential for fish larvae and juveniles. One might speculate that specific other ingredients of DFZO and not the added zooplankton components improved performance of grayling larvae and juveniles. However, unpublished experiments indicate that DFZO without 
zooplankton resulted in similar malformations as observed in the present study with FFS.

(2) Fish fed exclusively with DFS (regime 2) and to a smaller extent those adapted to FSS at an early development stage (regime 3) developed malformations and abnormal behaviour. The conducted microscopical investigations demonstrated exaggerative gas accumulations in the abdominal cavity and in the intestine of abnormal fish. Gas accumulations must be considered as causative for impaired swimming balance, compression of the vertebral column and possibly also for different kinds of tissue lesions. It might be speculated that they derive from inadequate digestibility of the dry food. Contradictory to this assumption is the result that fish fed with FSS had a high weight increase even extending that of the live zooplankton control after $49 \mathrm{~d}$. This might indicate that FSS has all components promoting fast growth of grayling but lacks some basic nutritional requirements. Also different kinds of preservatives in fish food could lead to problems in digestibility.

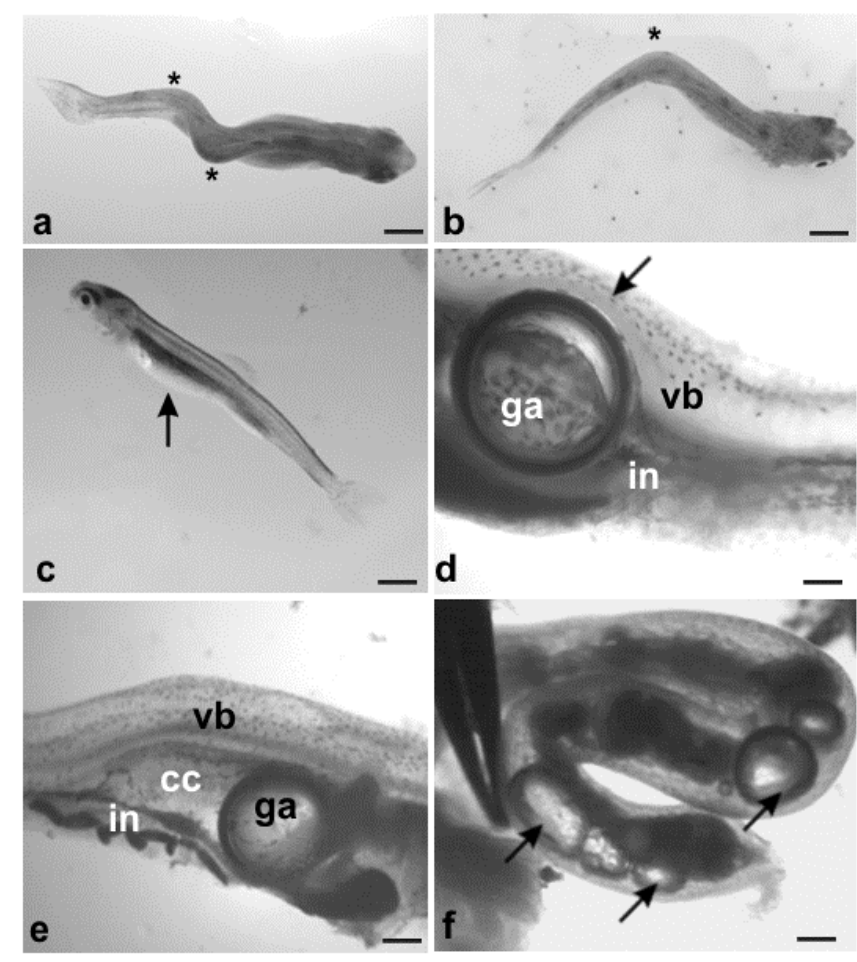

Figure 2. Malformations observed in grayling juveniles

Figure 2a: Grayling with double bent tail (asterisks). Scale bar $=2.9 \mathrm{~mm}$. Figure 2b: Grayling with single bent tail (asterisk). Scale bar $=2.5 \mathrm{~mm}$. Figure 2c: Grayling with enlarged abdominal cavity (arrow). Scale bar $=3.1 \mathrm{~mm}$. Figure 2d: Gas accumulation (ga) inside the intestine (in) deforming the vertebral column (vb). Scale bar $=0.4 \mathrm{~mm}$. Figure 2e: Gas accumulation (ga) inside the coelomic cavity (cc) compressing (arrow) the vertebral column (vb). in - intestine. Scale bar $=0.5 \mathrm{~mm}$. Figure 2f: Gas accumulations in the intestine (arrows). Scale bar $=0.2 \mathrm{~mm}$.

A key result of the present study is the observation that malformations and abnormal behaviour were reversible. When instead of FSS live zooplankton was administered to the abnormal fish, malformations were compensated and decreased to $<2 \%$ within 1 to 2 weeks. This result indicates, that malformations are indeed food related and not caused by an undiagnosed type of fish disease. However, the exact physiological reasons for the gas accumulations remain unclear from the presented data and need deeper and basic investigations. In cultured Atlantic cod, Gadus morhua, larvae Grotmol, Kryvi, and Totland (2005) observed a deformation of the notochord by pressure from the swim bladder. In larvae of cultured burbot, Lota lota, swimbladder hyperinflation was observed during artemia feeding leading to severe notochord compression (Rekecki et al., 2014). Also in these two species the physiological reasons for these alterations remained unclear. Eckmann (1987) found that grayling larvae fed with inadequate food revealed a disturbed fat absorption which was explained to be due to the inability of enterocytes to synthesize chylomicrons.

(3) Fish fed exclusively with DFZO (regime 1) exhibited also increased mortality and decreased growth but no 
malformations evolved. This observation could be explained in two ways. It is possible that DFZO is not optimal for more advanced live stages of grayling. It is also possible that the negative effects are due to inadequate food production. DFZO was designed as larvae food with particle sizes of maximally $400 \mu \mathrm{m}$. Bigger particles could only be fed as crumbles probably having lower stability than DFS.

In summary, the present study shows that rearing of grayling is possible exclusively on dry food under intensive farming conditions. During the first 14 days of feeding a specific dry food containing zooplankton components should be administered to avoid abnormalities in development. Commercial available salmonid fry food was suitable thereafter. Under these conditions the survival rates $48 \mathrm{~d}$ after first feeding were $85 \%$, the rates of malformation $<1 \%$ and fish increase in length was circa 2 -fold and in weight 6-fold. For practical application, the switch from DFZO (or live food) to DFS must be exactly timed to avoid the development of malformations caused by too early administration of FSS and reduced growth caused by prolonged administration of DFZO.

\section{References}

Abi-Ayad, A., \& Kestemont, P. (1994). Comparison of the nutritional status of gold fish (Carassius auratus) larvae fed with live, mixed or dry diet. Aquaculture, 128, 163-176. http://dx.doi.org/10.1016/0044-8486(94)90111-2

Bergmeyer, H. U. (1985). Methods of enzymatic analysis. Weinheim, VCH Verlagsgesellschaft.

Carlstein, M. (1993). Natural and artificial, dry starter diets: effects on growth and survival in intensively reared European grayling. Aquaculture International, 1, 112-123. http://dx.doi.org/10.1007/BF00692615

Chaplin, M. F., \& Kennedy, J. F. (1986). Carbohydrate analysis: A practical approach. Oxford, England, IRL Press Limited.

Chaudhry, K. (1989). Biochemical Techniques. New Delhi, Medical Publishers.

Eckmann, R. (1987). Pathological changes in the midgut epithelium of grayling, Thymallus thymallus L., larvae reared on different kinds of food, and their relation to mortality and growth. Journal of Fish Diseases, 10, 91-99. http://dx.doi.org/10.1111/j.1365-2761.1987.tb00724.x

Evejemo, J. O., Reitan, K. I., \& Olsen, Y. (2003). Copepods as live food organisms in the larval rearing of halibut larvae (Hippoglossus hippoglossus L.) with special emphasis on the nutritional value. Aquaculture, 227, 191-210. http://dx.doi.org/10.1016/S0044-8486(03)00503

Grotmol, S., Kryvi, H., \& Totland, G. K. (2005). Deformation of the notochord by pressure from the swim bladder may cause malformation of the vertebral column in cultured Atlantic cod Gadus morhua larvae: A case study. Diseases of Aquatic Organisms, 65, 121-128. http://dx.doi.org/10.3354/dao065121

Harris, K. C., \& Hulsman, P. F. (1991). Intensive culture of lake whitefish (Coregonus clupeaformis) from larvae to yearling size using dry feeds. Aquaculture, 96, 255-268. http://dx.doi.org/10.1016/0044-8486(91)90156-2

Lahnsteiner, F., Kletzl, M., \& Weismann, T. (2009). The risk of parasite transfer to juvenile fishes by live copepod food with the example Triaenophorus crassus and Triaenophorus nodulosus. Aquaculture, 295, 120-125. http://dx.doi.org/10.1016/j.aquaculture.2009.06.038

Lahnsteiner, F., Mansour, N., \& Caberlotto, S. (2010). Composition and metabolism of carbohydrates and lipids in Sparus aurata semen and its relation to viability expressed as sperm motility when activated. Comparative Biochemistry and Physiology, Part $B \quad$ 157, 39-45, http://dx.doi.org/10.1016/j.cbpb.2010.04.016

Lahnsteiner, F., Kletzl, M., \& Weismann, T. (2012). Rearing of burbot, Lota lota (Pisces, Teleostei), larvae with zooplankton and formulated microdiets. Journal of Agricultural Science, 4, 269-277. http://dx.doi.org/10.5539/jas.v4n9p269

Lowry, O. H., Rosenbrough, N. J., Farr, A. L., \& Randall, R. J. (1951). Protein measurement with Folin phenol reagent. The Journal of Biological Chemistry, 193, 265-275.

Lowry, R. R., \& Tinsley, I. J. (1976). Rapid colorimetric determination of free fatty acids. Journal of the American Oil Chemists'Society, 53, 1558-9331.

Luczynski, M., Zaporowski, R. R., \& Golonka, J. S. (1986). Rearing of European grayling, Thymallus thymallus L., larvae using dry and live food. Aquaculture Research, 17, 275-280. http://dx.doi.org/10.1111/j.1365-2109.1986.tb00114.x

Mitra, G., Mukhopadhyay, P. K., \& Ayyappan, S. (2007). Biochemical composition of zooplankton community 
grown in freshwater earthen ponds: Nutritional implication in nursery rearing of fish larvae and early juveniles. Aquaculture, 272, 346-360. http://dx.doi.org/10.1016/j.aquaculture.2007.08.026

Ocvirk, J. \& Vork, J. (1986). The role of live zooplankton in the artificial rearing of the grayling (Thymallus, thymallus). Ichthyos, 3, 8-12.

Rekecki, A., Meeus, W., Chiers, K., Adriaen, J., Boyen, F., Declercq, A., ... Decostere, A. (2014). Swimbladder hyperinflation in burbot Lota lota L. larvae. Aquaculture Research (Early view online version). http://dx.doi.org/10.1111/are.12499

Sekino, T., Nakanishi, M., Ishida, Y., Isomura, S., Tsuge, S., Ohtani, H., \& Kimoto, T. (1997). Inter-and intraspecific differences in fatty acid composition of freshwater crustacean zooplankton. Freshwater Biology, 38, 611-618. http://dx.doi.org/10.1046/j.1365-2427.1997.00240.x

Støttrup, J. G. (2000). The elusive copepods: Their production and suitability in marine aquaculture. Aquaculture Research, 31, 703-711. http://dx.doi.org/10.1046/j.1365-2109.2000.318488.x

\section{Copyrights}

Copyright for this article is retained by the author(s), with first publication rights granted to the journal.

This is an open-access article distributed under the terms and conditions of the Creative Commons Attribution license (http://creativecommons.org/licenses/by/3.0/). 